\title{
REREADING THE DAVID-MEPHIBOSHETH NARRATIVE FROM A PASTORAL HERMENEUTICAL PERSPECTIVE: \\ A SOCIAL MODEL ${ }^{1}$
}

Temba Rugwiji

Department of Old Testament and Ancient Near Eastern Studies

University of South Africa

\begin{abstract}
People with disabilities have experienced varying degrees of acceptance throughout recorded history. ${ }^{2}$ This paper articulates that modern societies tend to discriminate against people with disabilities whom they perceive as incapacitated to do what non-disabled people can do. Not many biblical scholars have attempted to appropriate Mephibosheth's deformity with disability phenomena in our modern society today. This article argues that the biblical narrative about Mephibotheth's deformity should inform members of the public to be proactive by responding positively to people with disabilities in our modern society. The narrative is reread from a pastoral hermeneutical perspective in which a social model of disability is employed to explore the ambivalence associated with disability in our society today. In the final analysis, I will make recommendations towards emancipation of people with disabilities.
\end{abstract}

Key Words: Rereading, Mephibosheth, Disability, Society, Social Model

\section{Introduction}

As rightly put by Mary Jo Iozzio (2011:139) people with disabilities have experienced varying degrees of acceptance throughout recorded history. Modern societies tend to perceive people with disabilities as incapacitated to do what non-disabled people can do. This perception discriminates against people with disabilities in many respects, including career opportunities. This article employs the biblical story of Mephibosheth's deformity as an example to explore the complexities associated with the phenomenon of disability today.

Disabilities of various types are found everywhere in the world: the visually impaired, the hearing impaired, the intellectually challenged, the paralytic, the epileptic, the leper, among others. Added to that endless list are malformations, deformations or disruptions, ${ }^{3}$

Under the social model, disability is caused by the society in which we live and is not the "fault" of an individual person with disability. For more details, see Mike Oliver, The politics of disablement (London: Macmillan, 1990); Tom Shakespeare \& Nicholas Watson, "Defending the social model," in Disability Rights (ed. Peter Blanck, Burlington, VT: Ashgate, 2005), 425-432.

2 Izzio's view is substantiated by the notion that our rereading of the ancient biblical text depicts some degree of discrimination against people with disabilities. Added to that are negative perceptions on the part of modern societies toward the phenomenon. See Mary Jo Iozzio, "Solidarity: Restoring communion with those who are disabled," Journal of Religion, Disability \& Health 15 (2011), 139.

3 Michael M Cohen, The child with multiple birth defects (New York: Raven Press, 1982), 1. 
which include plantar overgrowth (Cohen and Hayden 1979:291). As correctly remarked by Eiseland (1994:13), living with disability is indeed difficult. The difficulty, as Nancy L Eiseland laments, is aggravated by the fact that societies regard people with disabilities as incapacitated to do what non-disabled people can do, which naturally segregates and discriminates against the former in many respects.

Mephibosheth was five years old when the news about the death of both Mephibosheth's father and grandfather, Jonathan and Saul, respectively, came from Jezreel. His nurse hurriedly picked him up and fled, but as she hurried to leave, he (Mephibosheth) fell and became crippled in both feet (cf 2 Sm 4:4; 9:3, 13; 19:24-26).

In our modern society, several models have characterised the history of disability particularly in the West, such as: the religious model, the medical/genetic model, and more recently the social/human-rights model (Clapton \& Fitzgerald 1997). Due to space, this study will examine only two of these models, namely: the social model and the medical model of disability. The story of Mephibosheth's deformity in this discourse is intended to serve as a social model of disability ${ }^{4}$ (as opposed to limiting the condition to the medical model of disability) to illuminate the ambivalence associated with disability. Jeremy Schipper deviates from using the phrase "social model of disability" and prefers to describe it as the "minority model of disability" (2006:7). For our modern readers it becomes apparent that the social model of disability is the strength of this study out of which my rereading of the David-Mephibosheth narrative from a pastoral hermeneutical perspective 5 derives. This article attempts to conscientise modern societies to shun from perceiving disability as a hindrance for involvement, accommodation and integration into economic and socio-political activities.

\section{The David-Mehiphibosheth Narrative within the Deuteronomistic History}

The book of Deuteronomy plus many portions of the 'framework' of the historical account that runs from Joshua through 2 Kings is usually described as the Deuteronomistic History (hereafter to be shortened as 'DH'). To be precise, DH refers to the books of Deuteronomy, Joshua, Judges, Samuel, and Kings (Noth 1967:180-182). They are also called the books of kings because they portray the Davidic theme. ${ }^{6}$ According to this theory, every king from the lineage of David is portrayed as 'good,' such as Josiah being described as "did not turn aside to the right hand or left" (Dt 5:32; Jos 1:7; Ki 22:2), or "Asa did what was right in Yahweh's sight as David his father had done" (1 Ki 15:11). David was the king over Israel, after Saul - Israel's first king (cf Gunn 1980:23).

The comparison that is made about Israel's first two kings is usually angled towards glorifying the Davidic kingship, and not Saul's. Saul's reign is portrayed in 1 Samuel as a period of national trauma, particularly from the Philistines. Saul's personal weaknesses ultimately contributed to David's success (McNutt 1999:105). McNutt's assumption could further be described as a "common Deuteronomistic language." David is viewed by the

\footnotetext{
Both the social and medical models of disability shall be critically explored under a separate heading below. The phrase pastoral hermeneutical perspective refers to the interpretation from a pastoral (clerical) perspective. It is employed in this study to express the idea that this argument derives from a personal pastoral experience on the Phenomena under discussion. I have had numerous acquaintances and interaction with people with disabilities, including academic research.

6 Iain W Provan, Hezekiah and the books of Kings: A Contribution to the debate about the composition of the Deuteronomistic History (Berlin: Walter de Gruyter, 1988), 91.

Gerald E Gerbrandt, Kingship according to the Deuteronomistic History (Atlanta: Scholars Press, 1986), 49.
} 
biblical text as promissory figure. ${ }^{8}$ One passage states that when Samuel anointed David, "the spirit of Yahweh came mightily upon David from that day forward" (Anderson 1986:220). This Davidic theme is also apparent in the New Testament tradition in which Jesus Christ is said to be "the son of David" (Cf Mt 9:27; 12:23; 21:9, 15). The New Testament faith traces Christ's right to rule to his descent from David (La Sor et al. 1982:247). However, the picture of David's kindness to the house of Saul and his profound regard for Jonathan sketched throughout the narrative, is enhanced by his mercy to Jonathan's son Mephibosheth.'

\section{Covenant-making in the Old Testament}

In the Old Testament, a covenant formed part of the joinery between people and the land. God established his covenant with Noah and his descendants, and all generations to come (Gn 9:8-16). The following exegetical analysis of 2 Samuel 9:7-10 is necessary in view of the ideology of covenant-making in the Old Testament. Jonathan, David's friend, had a son named Mephibosheth (2 Sm 9:3, 7). Saul, Jonathan and Saul's other two sons, Abinadab and Malki-Shua, had died in battle against the Philistines when Israel was defeated at Mount Gilboa (1 Sm 31:1-2). David's request: "Is there anyone still left of the house of Saul to whom I can show kindness for Jonathan's sake?” (2 Sm 9:1) motivates Ziba, Saul's servant to suggest Mephibosheth to David.

The covenant David and Jonathan entered into was a kind of contract (1 Sm 18:1-4). The bond between them was reaffirmed in 1 Samuel 20:16-17, as well as when Jonathan saved David in yet other killing plots by Saul (1 Sm 20:24-29; 23:15-18). Among Saul's sons who were handed over by David to the Gibeonites to be killed, Mephibosheth was spared "because of the oath before the Lord between David and Jonathan, son of Saul" (2 Sm 21:7). Restoring Saul's inheritance to Mephibosheth by King David was a show of commitment to the covenant between David and Jonathan. The covenant between David and Jonathan had a binding effect on their respective descendants as well (Gn 9:8-17; Ex

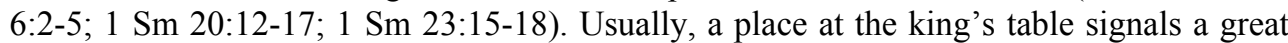
honour (I Ki 2:7), which is also repeated five times in 2 Samuel 9:7, 10, 11, 13; 19:28 (Schipper 2006:112). Schipper's analysis concurs with the sentiments by Manning (1990:57) in which he affirms that in the Near East, to share a meal with someone is a guarantee of peace, trust, fraternity and forgiveness. Mephibosheth had become a recipient of kindness and honour as a result of a covenant made between David and Jonathan.

\section{Restoration of Land: Remembering the Covenant}

David restored to Mephibosheth the land that belonged to Saul, his grandfather (9:7a) for the sake of the covenant David had made with Jonathan (9:7b). For Mephibosheth land could function as a source of income and a survival strategy (Scheepers 2011:33). Survival strategies, as Scheepers remarks, are the measures which a family, community or a nation could employ for the survival of its people. Saul's servant, Ziba, would play the role of a farmer for Mephibosheth. David summoned Ziba to farm the land "for him and bring the crops, so that your master's grandson may be provided for" (2 Sm 10a). It is from the produce of the land that Mephibosheth had to live. In his reference to both the geological

8 Provan, Hezekiah and the books of Kings: A contribution to the debate about the composition of the Deuteronomistic History, 94.

9 William Sanford La Sor, Old Testament survey: The message, form and background of the Old Testament (Michigan: William B Eerdmans Publishing Company, 1982), 250. 
and agricultural vitality of land, Krüger (2003:74) posits that the place where one spends one's childhood remains part of one's soul. Without this source of income, it would keep both Mephibosheth and his family entrapped in poverty since one more 'mouth' needed to be fed (Spangenberg 2011:17).

\section{Deformity in the Bible}

During ancient biblical times, the condition of deformity was not uncommon. However, healing had not been part of the tradition, nor was it part of the scribes and the Pharisees (Galipeau 1990:59). Although not explicitly mentioned, Galipeau's assertion portrays a notion of moving away from the medical model of disability. ${ }^{10}$ It is not clear whether ancient biblical societies understood the social model approach. However, the Torah taught that the entrants to the temple altar or priesthood should not have any kind of defects: blindness, lameness, crippled, dwarfed, running sores or damaged testicles (Lv 21:16-24). Eiseland (1994:71) argues that these and similar passages have historically been used to warrant barring persons with disabilities from positions of ecclesiastical visibility and authority. Eiseland further concurs that according to biblical standards, people with disabilities lack perfection and embody un-wholeness. ${ }^{11}$

Viewed at from the religious/moral perspective, the biblical tradition portrays the picture that disability has something to do with the deity or malicious sub-deities (Fountaine 1996:21-26). Further, the biblical text acknowledges that Yahweh is one who makes the deaf, the blind, and crippled (Ex 4:11). It is Yahweh who creates the disabled (Ex 4:11) and who can reverse the disability (Ps 146:8). In some instances disability is depicted to be a result of $\sin (\operatorname{Lk} 5: 23$; Jn 5:14). The disciples' question to Jesus concerning the man who was born blind, suggests that Jesus' followers understood disability to be a result of sin either by the parents or the child born blind (Jn 9:1-2).

In contrast the books of Leviticus and Deuteronomy teach about treating people with disabilities favourably ( $\mathrm{Lv}$ 19:14; Dt 27:18). As opposed to the Old Testament exclusivity into the priestly office of people with disabilities, Jesus and his disciples healed those with various deformities (Jn 5:14; Jn 13:10-17; Acts 3:1-10; 6:1-6).

The contentions by Eiseland ${ }^{12}$ that the modern church as part of a larger society discriminates against people with disabilities depict a continued violation and contravention of the efforts by government through legislation passed by Parliament which seeks to uphold the rights of and to protect people with disabilities from further discrimination. ${ }^{13}$ Perhaps the church needs to be reminded about the principle of ancient Israel of "people helping people, ignoring all barriers and all questions about the worthiness of those being helped - that is the principle ancient Israel had learned and then forgotten" (Vonhoff 1971:14). The above conclusion by Vonhoff draws us to discuss in detail the following models of disability: the social model of disability and the medical model of disability.

10 The medical model of disability emphasises that a person with disability precisely needs medical attention. See Paul Hunt, Stigma: The experience of disability (London: Geoffrey Chapman, 1966).

11 Cf Nancy L Eiseland, The disabled God: Toward a liberatory theology of disability (Nashville: Abingdon Press, 1994), 72; Deborah B Creamer, Disability and Christian theology: Embodied limits and constructive possibilities (New York, NY: Oxford University Press, 2009).

12 Nancy L Eiseland protests that societies regard people with disabilities as incapacitated to do what nondisabled people can do. See Eiseland, The disabled God: Toward a liberatory theology of disability, 71.

13 I have chosen South Africa and Zimbabwe, respectively, as examples in this regard. The South African and Zimbabwean contexts are discussed under the heading: The social and medical models of disability: A critical engagement. It is argued that people with disabilities should be accorded their rights and justice. 


\section{The Social and Medical Models of Disability: A Critical Engagement}

Carson (2009) provides that the social model of disability has been developed by people with disability in response to the medical model and the impact it has had on their lives. Under the social model, ${ }^{14}$ disability is caused by the society in which we live and is not the 'fault' of an individual person with disability. The social model takes account of people with disability as part of our economic, environmental and cultural society, collectively described by O'Halloran (2007) as a 'social inclusion.' For example, the social model of dyslexia (Cooper 2006) states that dyslexia is not a deficit but an experience that arises out of natural human diversity. It follows that the social model directs our attention to the particularities of society rather than to the particularities of being human (Reinders 2008:59). In making the above assertion, Hans S Reinders suggests 'being human' includes a person with disability. The reconstructionist approach, ${ }^{15}$ as social model is broadly referred to, seeks to conscientise societies to re-evaluate their own perceptions toward people with disabilities as they make attempts to remove barriers and constraints which prohibit social interactions which deny social inclusion.

In contrast, the medical model of disability the person with disability is the problem, not society. As rightly echoed by Deborah Kaplan, a medical model regards disability as a defect or sickness which must be cured through medical intervention. ${ }^{16}$ Further, Schipper (2006:7) advances the opinion that the medical model understands disability as a biological defect within a person's body that needs to be cured. Thus, Schipper's view informs us that the medical model of disability is the opposite of the social model. In addition, Fallon $(2007)^{17}$ concurs that the medical model regards disability as a sociopolitical model by which illness or disability, being the result of a physical condition, and which is intrinsic to the individual, may reduce the individual's quality of life and causes clear disadvantages to the individual. It is apparent that much attention has been paid to the social model of disability as an 'inclusively-accepted' model. Unlike the medical model, the social model (described by Jeremy Schipper as the minority model) does not see people with disabilities as isolated subjects needing medical attention. Rather, they are members of the oppressed group subjugated by 'able-bodied'18 ideologies encoded into larger social structures (Schipper 2006:7).

The social model of disability has been a social tool to shift the focus of disability as individual deficit to disability as well as a social construction in an oppressive society (Peters et al. 2009:543). The social model of disability has been prompted and popularised by the fact people with disabilities have often been denied choice and control in their lives (Williams et al. 2009:815), which resulted in the formation of an organisation such as the World Program of Action (WPA), in which people with disability had some control. The WPA as a "movement has a long way to go and needs to result in changes in not just the

14 See Shakespeare \& Watson, "Defending the social model," 425-432.

15 Hans S Reinders, Receiving the gift of friendship: Profound disability, theological anthropology, and ethics (Grand Rapids: William B Eerdmans Publishing company, 2008), 59.

16 Deborah Kaplan, "The definition of disability." No pages. Online: http://www.accessiblesociety.org/topics/demographics-identity/dkaplanpaper.htm\#statexperts. Accessed 6 October 2011

17 For further reading on the medical model of disability, see John Swain, Sally French and Catherine Cameron, Controversial issues in a disabling society (Buckingham: OU Press, 2003).

18 As opposed to Jeremy Schipper's description of "able-bodied," I choose to describe them as "non-disabled" people. 
behaviour but in the attitude of society" (Isaac et al. 2010:627), which is "widening the scope of human rights to equal opportunities with regards to people with disabilities." 19

Barnes and Sheldon (2010:771) have lamented that the spread of free market economics has generated huge inequalities within and between nations and this has had an important impact on people with disabilities. People with disabilities are the poorest of the poor in all societies, largely among the developing countries. Within the developing world, phenomena of disabilities have been aggravated by poverty, political crisis and civil wars, among them governance problems, the large disparity between the rich and poor, and the difficulties with accessing adequate housing, infrastructure and basic services (Mji et al. 2011:365). Due to constraints of space, I have chosen the South African and the Zimbabwean contexts as representative examples to explore on policy issues related to disability phenomena within the Southern African context.

Swartz and Watermeyer (2006:1) remark that people with disabilities in South Africa are collectively amongst the nation's poorest, even within a country characterised broadly by atrocious levels of economic inequality. Even though the editors of this edition of Disability and social change: A South African agenda ${ }^{20}$ advocate for "a dialogue, and a growing exploration regarding what it means to be a disabled South African," the attempt cannot exclusively be limited to the South African context. It should cover all other strata of human existence. As affirmed by Howell et al. (2006:46) the new (South African) constitutional framework also marked an important milestone in the struggle of people with disabilities. The constitution's recognition that people with disabilities in South Africa have been and continue to be discriminated against because of their disability, means that disability has become an important consideration in the new legislation and in policy documents that make up South Africa's legal and policy framework. ${ }^{21}$

In Zimbabwe, on the other hand, people with disability had to form a self-support system in an attempt to resist oppression, and in 1982, an organisation known as the National Council of Disabled People in Zimbabwe (NCDPZ) was finally launched (Peters et al. 2009:550). It was largely through the organised efforts of NCDPZ that the Disabled Persons Act of 1992 was passed by the Zimbabwean Parliament. ${ }^{22}$ The fact that it took almost ten years for such a policy to be implemented reinforces the idea of resistance against the initiative.

In numerous instances, people with disabilities are discriminated against at the workplace, the practice that can suitably be described as social barrier. ${ }^{23}$ Naraine and Lindsay (2011:389) suggest that organisations need to be proactive in developing concrete solutions to remove social barriers and facilitate the social inclusion of employees who are visually impaired or who have low vision into the workplaces. Arguing for the cause of people with disability, Boeltzig et al. (2009:753) reaffirms that while many people with

19 Rebecca Isaac, William Dharma B Raja and M. P. Ravanan, "Current issues: Integrating people with disabilities: their right - our responsibility,” Disability \& Society 25/5 (2010), 627-630.

20 See Brian Watermeyer, Leslie Swartz, Theresa Lorenzo, Marguerite Schneider and Mark Priestley, Disability and social change: A South African agenda (Cape Town: HSRC Press, 2006), 2.

21 See Colleen Howell, Shuaib Chalklen and Thomas Alberts, "A history of the disability rights movement in South Africa," in Brian Watermeyer et al 2006:46-83.

22 See Susan Peters, Susan Gabel and Simon Symeonidou, "Resistance, transformation and the politics of hope: Imagining a way forward for the disabled people's movement," Disability \& Society 24/5 (2009), 550.

23 Social barrier is simply a layer that we have built around ourselves to protect us from the outside world. The social model has been developed with the aim of removing social barriers so that people with disabilities have the same opportunity as everyone else to determine their own life styles. See Solace Swanson, "Social barriers.” No pages. Online: http://ezinearticles.com/?Social-Barriers\&id=733196. Accessed 7 October 2011. 
disabilities are becoming and remaining employed, their employment rates remain substantially lower than those for the non-disabled. One of the reasons attributed to the negative attitude in employing people with disabilities is the aspect of 'control' and the 'type' of employer. Giving people with disabilities control of their support needs is an integral aspect of independent living (Prideaux et al. 2009:559). Prideaux's view can be substantiated by success stories in which support needs for people with disabilities at institutionalised centres were fundamentally under the control of people with disabilities themselves, a good example of which is exhibited at Danhiko Project ${ }^{24}$ in Zimbabwe.

\section{Rereading the David-Mephibosheth Narrative from a Pastoral Hermeneutical Perspective: A Social Model}

\section{Societal Perception of People with Disability}

Dominant perceptions about disability within society viewed impairment as a personal tragedy and assumed that people with disabilities wanted to be 'cured' (Beauchamp-Pryor 2011:5). ${ }^{25}$ Though not clearly elaborated in Beauchamp-Pryor's statement above, inclination towards the medical model of disability has led modern societies to discriminate against, isolate and marginalise people with disabilities whom they perceive as needing medical attention as opposed to social accommodation, inclusion and psychosocial support. As rightly echoed by Whybray (1990:9) there is a gross unequal distribution of wealth between the affluent and the marginalised in today's world. This gap between the "affluent and the marginalised" as Whybray describes it, subsequently results in stigma and trauma. Gelya Frank elaborates this circumstance by saying despite their capacity of willingness to participate in 'normal' society, stigmatised individuals are often barred from equal access in such domains as education, dating and marriage, employment, and use of public facilities. ${ }^{26}$ Hahn (1988:39-47) further remarks that people with disabilities are thoroughly marked in a society that prizes autonomy and intelligence. In view of Hahn's analysis, the attitude naturally raises a feeling of isolation and some kind of quarantine. It is further argued by Swain et al. (1993) that prejudice is associated with the recognition of difference, and people with disabilities are not seen as normal in the eyes of 'non-disabled' people.

\section{The Possible Implications of Mephiboaheth's Use of the 'Dead Dog' Metaphor}

Bowing down in honour before David, Mephibosheth viewed himself as a dead $\operatorname{dog}(2 \mathrm{Sm}$ 9:8). At this point, there is need to analyse this 'dead dog' metaphor. When man first began to live with dogs, the latter undoubtedly acquired a universal importance in everyday human life (Bergler 1988:2). Bergler adds that since the dawn of humankind, animals have always played an important part in the complex scheme of human relationships. ${ }^{27}$ Dogs

24 As of 2010, Danhiko Project in Zimbabwe was under the directorship of Mr G Majonga, who uses a wheelchair.

Various capacities of leadership at Danhiko Project are under the leadership of people with disabilities. I was privileged to carry out a research study at Danhiko Project in 2010 while on attachment for the research project on Community Development and Humanitarian Project Management offered by the University of Zimbabwe.

25 This observation by Karen Beauchamp-Pryor was motivated by the medical model of disability already discussed above.

26 See Gelya Frank, "Beyond stigma: Visibility and self-empowerment of persons with congenital deficiencies," Journal of Social Issues 44/1 (1988), 96.

27 See Reinhold Bergler, Man and dog: The psychology of a relationship (Oxford: Blackwell Scientific Publications, 1988), 1. 
provide security, protection, warning of impending danger, and good company. In this sense, Mephibosheth would become David's 'helpless' dog because of his physical challenge. Added to that is Fokkelman's idea that dogs are rightly regarded as the epitome of loyalty. Mephibosheth's disability reinforces the idea that the narrative presents him in a more 'loyal' light at this early point in the story. ${ }^{28}$ In view of that, it might be supposed that Mephibosheth was showing some kind of loyalty, fear or respect, as the 'dead dog' statement is preceded by 'bowing down' before David (2 Sm 9:8).

On the other hand, Mephibosheth might have had some phobia towards David. Many rabbinic interpreters note that Mephibosheth had good reason to fear because David might have wanted to avenge Saul's earlier persecution by killing all his descendants (Yerushalmi 1993:205-206). Yerushalmi's supposition could be correct given the fact that earlier on, David handed over Saul's seven sons to be killed by the Gibeonites (Blenkinsopp 1992:8990).

Alternatively, a 'dead dog' metaphor might be explained as 'posing no threat' because a dead dog is harmless. Moreover, someone's chronic illness often becomes the person's identity (Larsen 2009:5). Larsen's assertion is strengthened by the general perception among members of society towards an individual suffering from some kind of cancer, whom they label as 'that person with cancer.' In addition, the 'dead dog' metaphor seems to implicate one of the 'death wishes' that some sufferers of pain usually make. It is a kind of euthanasia (Thomasma et al. 1998:11). ${ }^{29}$ When pain worsens as a result of one's physical condition, people would regrettably plead for death to overtake them. ${ }^{30}$ Mephibosheth's 'dead dog' metaphor seems to carry similar connotations.

By contrast, it is axiomatic in Judaism that human life is of infinite value and that all efforts must be applied to heal, to cure illness, and prolong life (Rosner 1990:65). Judaism never condones the deliberate destruction of human life except in judicial execution for certain criminal acts, in self-defence, or in time of war. ${ }^{31}$

\section{Disability and Poverty}

Mephibosheth might have been poor; his 'dead dog' statement to David idealises this view (2 Sm 9:8). Poverty can be defined in many ways: lack of food, clothing, and housing, to name just a few. Poverty is an enemy that hinders one's independence from life meaning and from other people. Many poor homes have loving parents, and relatively stable environments, but a disproportionate number of the poor are exposed to harmful conditions (Collins 2007:218). In support of Collins's deduction, Spangenberg (2011:17) echoes the same sentiments where he explains that the majority of the people described as 'beggars' in

28 JP Fokkelman, Narrative art and poetry in the books Samuel: A full interpretation based on stylistic and structural analysis 4 Vols (Assen: Van Gorcum, 1981).

29 Euthanasia is sometimes described as "mercy killing." See Raphael Cohen-Almagor, Euthanasia in the Netherlands: the policy and practice of mercy killing. Dordrecht: Kluwer Academic Publishers, 2004. In scientific terms, the death induced by a physician on request by a sick patient is called euthanasia. For some Dutch citizens the Rommelink Commission's final report of September 10, 1991 justified their support of a policy in the Netherlands that openly allows physicians to assist their patients to die. For more information, see SA Abraham, "Euthanasia," in Medicine and Jewish Law Volume 1 (ed. Fred Rosner, London: Jason Aronson Inc, 1990), 125-136.

30 The biblical Job and Elijah felt the same. In both cases, the sufferers wished to die (Job 3:1ff; $1 \mathrm{Ki} \mathrm{19:4).}$ Jonah also prayed to die (Jnh 4:8). See James L. Crenshaw, "Human dilemma and literature of dissent," in Tradition and theology in the Old Testament (ed. Douglas A Knight, Sheffield: JSOT Press, 1990), 235-258.

31 See Fred F Rosner, "Communicable diseases and the physician's obligation to heal," in Medicine and Jewish Law Volume 1 (ed. Fred F Rosner, London: Jason Aronson, 1990), 65. 
the Bible are grossly affected by poverty, fuelled by poverty traps. Bringing the social model into perspective, David's invitation of Mephibosheth - who "dwelt in Jerusalem: for he did eat continually at the king's table, and was lame on both his feet" (2 Sm 9:13) renders support to the concept of 'inclusion' in terms of disability.

\section{Disability and Psychosocial Support}

The derision of people with disability is almost certainly a universal phenomenon, though likely to be more prominent in communities which lack a developed social conscience (Garland 1995:73). In spite of the "derision of people with disability" as Garland puts it, non-disabled members of society should strive to bring transformation in the lives of people with disabilities. 'Transformation' means change. To change means to make a reform. Where there is no difference in the same thing, change is absent. ${ }^{32}$

In numerous instances, good education, job opportunities, and other social and economic privileges are a preserve of the affluent in which people with disabilities do not have space. Where consideration for career has been given, the ratios of engagement between employees with disability and non-disable employees are usually in favour of the later (Boeltzig et al. 2009:753). If David had not shown kindness to Mephibosheth, his (Mephibosheth's) status in society would certainly have remained the same. Most people with disability lack psychosocial care and support. ${ }^{33}$ Communal responsibilities and community engagement, which naturally characterised most African cultures in the past, are under threat of extinction as a result of disintegration; modern African societies have largely become individualistic. In some instances, parents or relatives hide their children or their loved ones with disabilities because they feel ashamed to be associated with them, which they believe to be a result of evil or that they have been bewitched (Fountaine 1996: 21-26). This further aggravates the environment of people with disabilities in need of psychosocial support from members of the larger society or charity organisations.

\section{The Challenge of Mephibosheth's Disability for Today}

Society, charity organisations and government should collectively or individually play their roles to alleviate the crises associated with disability. Many people with disabilities require practical support from other people to accomplish the activities of daily living (Berthoud et al. 1993:55), and this includes the church. The Old Testament prophets continually stated that prayers and sacrifices were of no value unless there was concern for the poor and the needy (Am 5:21-24). Elelwani Farisani explains that the church should not only look at the question of the relationship between God and the poor but also at the relationship of the God of the poor (the God of life) with the economic political and social particularities of concretely oppressed people. $^{34}$

Theoretically, charity is concerned with the fact and effects of poverty and is focused on methods for directly alleviating the suffering of others (O'Halloran 2007:13). In support of O'Halloran's opinion of 'alleviating suffering,' it is suggested that one of the tasks to be undertaken by both people with disabilities and non-disabled persons is a continued search

See Ndabaningi Sithole, The secret of American success: Africa's great hope (S 1: s n., 1988).

33 The phrase psychosocial care and support in this case refers to food, care, shelter, health and treatment, education and association.

34 Elelwani Farisani, "The Naboth vineyard story (1 Kings 21) and poverty eradication," in The Bible and the eradication of poverty: Biblical Studies (Old Testament) Tutorial Letter OTS2604/501/3/2011 (eds. Eben Scheffler \& Schalk W van Heerden; Pretoria: Unisa, 2011), 61-72. 
for survival strategies. ${ }^{35}$ These survival strategies can include anything such as: empowerment through provision of skills' training, provision of resources and encouraging participation in some income-generating projects for self-sustenance.

\section{Conclusion}

In this article, it was explained that my rereading of the ancient biblical text has unearthed the prevalence of various illnesses and deformities, and illumined how the ancient biblical society perceived of people with disabilities. The Old Testament expresses that people with physical impairments were neither allowed to enter the altar nor serve as priests. However, the example of David who allowed Mephibosheth, a 'crippled' man, to "always eat at the king's table" depicts that certain individuals were committed to showing kindness to a section of society who was considered 'outcasts.' Having discussed the DavidMephibosheth narrative above, I have drawn the following conclusions, followed by recommendations toward the emancipation of people with disabilities.

The 'lameness' of Mephibosheth was not unique; it was a condition which affected humans everywhere during ancient biblical times. Mephibosheth did not see himself deserving honour from King David; hence he described himself as a 'dead dog.'

It was chronicled that dogs play crucial roles in providing security and protection for their masters and their properties. One would also regard Mephibosheth's 'dead dog' metaphor as a 'self-hate' language, which presumably is susceptible to suicide because of a negative perception of oneself and the sufferer would opt for euthanasia. I have argued that application of euthanasia to end one's life because of pain is not commendable. Judaism looked at it the same way.

In our modern societies, some guardians or parents hide their people with disabilities from the public as they feel ashamed to be identified with them. This is due to the popular belief that disability is a 'shameful' abnormality which is a result of a misdeed within the family or that they have been bewitched. Such misconceptions are some of the motivating factors which accentuate the killing of babies born with some form of physical impairment, as well as discriminating against people with disabilities at school, universities and in workplaces. I argued that killing babies because they are born with deformities should not be condoned.

In light of the issues discussed in this discourse, though not exhaustive, I recommended that negative attitudes which have increasingly characterised perceptions of modern societies towards disability should be discontinued. In contrast to the medical model of disability - which perceives a person with disability as the problem not society, and that disability is a defect which must be cured through medical intervention - I suggest the social model of disability in which disability is caused by the society in which we live. My argument for the social model of disability is motivated by the fact that it takes account of people with disability as part of our economic, environmental and cultural society. There is need for modern societies to accommodate, associate with and provide employment for people with disabilities.

35 See Coenraad Scheepers, "Survival strategies in ancient Israel: an archaeological perspective," in The Bible and the eradication of poverty: Biblical Studies (Old Testament) Tutorial Letter OTS2604/501/3/2011 (eds. Eben Scheffler \& Schalk W van Heerden; Pretoria: Unisa, 2011), 33. 


\section{BIBLIOGRAPHY}

Abraham, SA 1990. 'Euthanasia.' Pages 123-136 in Medicine and Jewish Law Volume 1. Edited by Fred Rosner. London: Jason Aronson Inc.

Anderson, W Bernhard 1986. Understanding the Old Testament. Fourth edition. Englewood Cliffs: Prentice Hall.

Barnes, Colin and Sheldon, Alison 2010. "Disability, politics and poverty in a majority world context." Disability \& Society 25/7, 771-782.

Beauchamp-Pryor, Karen 2011. "Impairment, cure and identity: 'Where do I fit in?", Disability \& Society 26/1 5-17.

Bergler, Reinhold 1988. Man and dog: The psychology of a relationship. Oxford: Blackwell Scientific Publications.

Berthoud, Richard, Lakey, Jane and McKay, Stephen 1993. The economic problems of disabled people. London: Policy Studies Institute.

Blenkinsopp, J 1992. The Pentateuch: An introduction to the first five books of the Bible. New York: Doubleday.

Boeltzig, Heike, Sulewski, Jennifer Sullivan and Hasnain, Rooshey 2009. "Career development among young disabled Artists.” Disability \& Society 24/6, 753-769.

Carson, G 2009. The social model of disability. Glasgow: Scottish Accessible Information forum.

Clapton, Jayne \& Fitzgerald, Jennifer 1997. "The history of disability: A history of 'Otherness,"' No pages. In the New Renaissance Magazine: Renaissance Universal 7/1. Online: http://www.ru.org/artother.html. Accessed 2 November 2011.

Cohen-Almagor, Raphael 2004. Euthanasia in the Netherlands: the policy and practice of mercy killing. Dordrecht: Kluwer Academic Publishers.

Cohen, M Michael 1982. The child with multiple birth defects. New York: Raven Press.

Cohen, M Michael and Hayden, PW 1979. "A newly recognised hamartomatous syndrome." Birth Defects 15/5B, 291-296.

Collins, Gary 2007. Christian counselling. 3rd ed. Nashville: Thomas Nelson.

Cooper, Ross 2006. A Social Model of Dyslexia. London South Bank University.

Creamer, B Deborah 2009. Disability and Christian theology: Embodied limits and constructive possibilities. New York, NY: Oxford University Press.

Crenshaw, L James 1990. "Human dilemma and literature of dissent," Pages 235-258 in Tradition and theology in the Old Testament. Edited by Douglas A Knight. Sheffield: JSOT Press.

Eiseland, L Nancy 1994. The disabled God: Toward a liberatory theology of disability. Nashville: Abingdon Press.

Fallon, Andrew. "Medical model of disability." No pages. Online: http://enabledisability.wordpress.com/2007/02/21/medical-model-of-disability. Accessed 5 October 2011.

Farisani, Elelwani 2011. "The Naboth vineyard story (1 Kings 21) and poverty eradication." Pages 61-72 in The Bible and the eradication of poverty: Biblical 
Studies (Old Testament) Tutorial Letter OTS2604/501/3/2011. Edited by Eben Scheffler and Schalk W van Heerden. Pretoria: Unisa.

Fokkelman, JP 1981. Narrative art and poetry in the books: A full interpretation based on stylistic and structural analysis 4 Vols. Assen: Van Gorcum.

Fountaine, R Carole 1996. "Disabilities and illness in the Bible: A feminist perspective." Pages 21-26 in A feminist companion to the Hebrew Bible in the New Testament. Edited by Athalya Brenner. Sheffield: Sheffield Academic Press.

Frank, Gelya 1988. "Beyond stigma: Visibility and self-empowerment of persons with congenital Deficiencies.” Journal of Social Issues 44/1, 95-115.

Galipeau, A Steven 1990. Transforming body and soul: Therapeutic wisdom in the gospel healing stories. New York: Paulist Press.

Garland, Robert 1995. The eye of the beholder: Deformity and disability in the GrecoRoman World. London: Gerald Duckworth \& Co. Ltd.

Gerbrandt, E Gerald 1986. Kingship according to the Deuteronomistic History. Atlanta: Scholars Press.

Gunn, M David 1980. The fate of King Saul: An interpretation of a Biblical Story. Sheffield: JSOT Press.

Hahn, H 1988. "The politics of human differences: Disability and discrimination.” Journal of Social Studies 44/1, 39-47.

Herzog, A. Albert 2006. Disability advocacy among religious organizations: histories and reflections. New York: Haworth Pastoral Press.

Howell, Colleen, Chalklen, Shuaib and Alberts, Thomas 2006. "A history of the disability rights movement in South Africa." Pages 46-83 in Disability and social change: A South African agenda. Edited by Brian Watermeyer et al. Cape Town: HSRC Press.

Hunt, Paul. “A critical Condition.” No pages. Online: http://www.leeds.ac.uk/disabilitystudies/archiveuk/archframe.htm. Accessed 5 Oct 2011.

Iozzio, Jo Mary 2011. "Solidarity: Restoring communion with those who are disabled." Journal of Religion, Disability \& Health 15, 139-152.

Isaac, Rebecca, Raja William B Dharma and Ravanan, MP 2010. "Current issues: Integrating people with disabilities: their right - our responsibility." Disability \& Society 25/5, 627-630.

Kaplan, Deborah. "The definition of disability." No pages. Online: http://www.accessiblesociety.org/topics/demographicsidentity/dkaplanpaper.htm\#statexperts. Accessed 6 October 2011.

Krüger, JS 2003. Sweeping whirlwinds. A study of religious change: Reformed religion and civil religion in the City of Pretoria (Tshwane). Pretoria: University of South Africa.

Larsen, D 2009. Phamala. "Chronicity." Pages 3-24 in Chronic illness: Impact and intervention 7th edn. Edited by Pamala D Larsen \& Ilene Morof Lubkin. Sudbury: Jones and Bartlett Publishers.

La Sor, William Sanford, Hubbard, David Allan \& Bush, William Frederic 1982. Old Testament survey: The message, form and background of the Old Testament. Michigan: William B Eerdmans Publishing Company.

Manning, B 1990. The ragamuffin gospel. Sisters OR: Multnomah Books. 
McNutt, Paula 1999. Reconstructing the society of ancient Israel. London: SPCK.

Mji, Gubela, Gcaza, Siphokazi, Swartz, Leslie, MacLachlan, Malcolm and Hutton, Barbara 2011. "Current issues: An African way of reworking around disability." Disability \& Society 26/3, 365-368.

Naraine, D. Mala \& Lindsay, Peter H 2011. "Social inclusion of employees who are blind or low vision." Disability \& Society 26/4, 389-403.

Noth, Martin 1967. Überlieferungsgeschichtliche Studien 1. 3rd ed. Tubingen: [s 1].

O’Halloran, Kerry 2007. Charity law and social inclusion: An international study. London: Routledge.

Oliver, Mike 1990. The politics of disablement. London: Macmillan.

Peters, Susan, Gabel, Susan and Symeonidou, Simoni 2009. "Resistance, transformation and the politics of hope: Imagining a way forward for the disabled people's movement." Disability \& Society 24/5, 543-556.

Prideaux, Simon, Roulstone, Alan, Harris, Jennifer, and Barnes, Colin 2009. "Disabled people and self-directed support schemes: reconceptualising work and welfare in the $21^{\text {st }}$ century."Disability \& Society 24/5, 557-569.

Provan, W Iain 1988. Hezekiah and the books of Kings: A Contribution to the debate about the composition of the Deuteronomistic History. Berlin: Walter de Gruyter.

Reinders, S Hans 2008. Receiving the gift of friendship: Profound disability, theological anthropology, and ethics. Grand Rapids: William B Eerdmans Publishing Company.

Rosner, Fred 1990. "Communicable diseases and the physician's obligation to heal." Pages 65-87 in Medicine and Jewish Law Volume 1. Edited by Fred Rosner. London: Jason Aronson Inc.

Scheepers, Coenraad 2011. "Survival strategies in ancient Israel: an archaeological perspective." Pages 33-45 in The Bible and the eradication of poverty: Biblical Studies (Old Testament) Tutorial Letter OTS2604/501/3/2011. Edited by Eben Scheffler and Schalk W. van Heerden. Pretoria: Unisa.

Schipper, Jeremy. Disability studies and the Hebrew Bible: Figuring Mephibosheth in the David story. New York: T\&T Clark, 2006.

Shakespeare, Tom \& Watson, Nicholas 2005. "Defending the social model." Pages 425432 in Disability Rights. Edited by Peter Blanck. Burlington, VT: Ashgate.

Sithole, Ndabaningi 1988. The secret of American success: Africa's great hope. s 1: s n.

Spangenberg, Izak 2011. "Extreme poverty and poverty traps." Pages 17-22 in The Bible and the eradication of poverty: Biblical Studies (Old Testament) Tutorial Letter OTS2604/501/3/2011. Edited by Eben Scheffler and Schalk W. van Heerden. Pretoria: Unisa.

Swain, John, Finkelstein, Vic, French, Sally \& Oliver, Mike 1993. Disabling barriers Enabling environments. SAGE: London.

Swain, John, French, Sally and Cameron, Catherine 2003. Controversial issues in a disabling society. Buckingham: OU Press.

Swanson, Solace. "Social barriers.” No Pages. Online: http://ezinearticles.com/?SocialBarriers\&id=733196. Accessed 7 October 2011. 
Swartz, Leslie and Watermeyer, Brian 2006. "Introduction and overview." Pages 1-6 in Disability and social change: A South African agenda. Edited by Brian Watermeyer et al. Cape Town: HSRC Press.

Thomasma, C David, Kimbrough-Kushner, T, Kimsma, K Gerrit \& Ciesielski-Carlucci, C (eds.) 1998. Asking to die: Inside the Dutch debate about euthanasia. London: Kluwer Academic Publishers.

Vonhoff, Heinz 1971. People who care: An illustrated history of human compassion. Philadelphia: Fortress Press.

Watermeyer, Brian, Swartz Leslie, Lorenzo, Theresa, Schneider, Marguerite and Priestley, Mark (eds.) 2006. Disability and social change: A South African agenda. Cape Town: HSRC Press.

Whybray, R Norman 1990. Wealth and poverty in the Book of Proverbs. Sheffield: JSOT Press.

Williams, Val, Pointing, Lisa and Ford, Kerrie 2009. "I do like the subtle touch': Interactions between people with learning difficulties and their personal assistants.", Disability \& Society 24/7, 815-828.

Yerushalmi, S 1993. The Book of Samuel II: Me'am Lo'ez. Edited and translated by M. Moshe. New York: Moznaim. 